\title{
Association between circulating galectin-3 levels and the immunological, inflammatory and nutritional parameters in patients with colorectal cancer
}

\author{
TATSUO SHIMURA ${ }^{1}$, MASAHIKO SHIBATA ${ }^{2}$, KENJI GONDA ${ }^{2}$, TAKAHIRO NAKAJIMA ${ }^{3}$, SHUN CHIDA $^{3}$, \\ MASARU NODA ${ }^{3}$, SATOSHI SUZUKI ${ }^{3}$, IZUMI NAKAMURA ${ }^{3}$, SHINJI OHKI $^{3}$ and SEIICHI TAKENOSHITA $^{3}$ \\ ${ }^{1}$ Department of Cancer Biology and Electronics, Fukushima Medical University, Fukushima 960-1295; \\ ${ }^{2}$ Department of Gastrointestinal Oncology, Saitama Medical University International \\ Medical Center, Hidaka, Saitama 350-1298; ${ }^{3}$ Department of Organ Regulatory \\ Surgery, Fukushima Medical University, Fukushima 960-1295, Japan
}

Received March 11, 2016; Accepted May 25, 2016

DOI: 10.3892/br.2016.696

\begin{abstract}
Galectin-3, a $\beta$-galactoside-binding lectin, exhibits pleiotropic biological functions and has a role as one of the immunological modulators. However, the associations between circulating galectin-3 and immunological, inflammatory and nutritional parameters have not yet been fully elucidated. The serum concentration of galectin-3 was examined in association with interleukin-10 (IL-10), IL-12 and IL17 production, lymphocyte stimulation, neutrophil/lymphocyte ratio (NLR), white blood cell count (WBC), C-reactive protein (CRP) and rapid turnover proteins, including retinol-binding protein (RBP), prealbumin (PA) and transferrin (TF) in 50 patients with untreated colorectal cancers. Significant increases $(\mathrm{P}<0.05)$ were observed in the serum galectin-3 levels in patients with untreated colorectal cancer $(9.6 \pm 4.5 \mathrm{ng} / \mathrm{ml})$ compared with the normal controls $(3.2 \pm 1.6 \mathrm{ng} / \mathrm{ml})$. Higher serum galectin-3 concentrations were observed in patients with colon cancer $(11.5 \pm 4.4 \mathrm{ng} / \mathrm{ml})$ compared to in patients with rectal cancer $(8.0 \pm 4.0 \mathrm{ng} / \mathrm{ml})(\mathrm{P}=0.005)$. The levels of circulating galectin-3 inversely correlated with the production of IL-10 ( $\mathrm{r}=-0.59, \mathrm{P}<0.001)$, and IL-12 ( $\mathrm{r}=-0.69, \mathrm{P}<0.001)$. Galectin-3 concentration also inversely correlated with the
\end{abstract}

Correspondence to: Professor Tatsuo Shimura, Department of Cancer Biology and Electronics, Fukushima Medical University, 1 Hikarigaoka, Fukushima 960-1295, Japan

E-mail: tshimura@fmu.ac.jp

Abbreviations: IL, interleukin; PBMCs, peripheral blood mononuclear cells; NLR, neutrophil/lymphocyte ratio; WBC, white blood cell count; CRP, C-reactive protein; RBP, retinol-binding protein; PA, prealbumin; TF, transferrin; ELISA, enzyme-linked immunosorbent assay

Key words: galectin-3, IL-10, IL-12, IL-17, rapid turnover protein, retinol binding protein, prealbumin, transferrin lymphocyte stimulation assay stimulation index $(r=-0.42$, $\mathrm{P}=0.021)$. However, the level of serum galectin-3 correlated with IL-17 production ( $\mathrm{r}=0.67, \mathrm{P}<0.001)$. Serum galectin-3 levels exhibited significant correlations with NLR $(r=0.41$, $\mathrm{P}=0.009)$, WBC $(\mathrm{r}=0.32, \mathrm{P}=0.035)$, and CRP $(\mathrm{r}=0.63$, $\mathrm{P}<0.001)$, and statistically significant inverse correlations with RBP $(\mathrm{r}=-0.45, \mathrm{P}=0.002), \mathrm{PA}(\mathrm{r}=-0.46, \mathrm{P}=0.001)$ and $\mathrm{TF}$ $(r=-0.72, P<0.001)$. Galectin-3 may be one of the key factors in the regulation of immunological, inflammatory and nutritional conditions.

\section{Introduction}

Galectin-3, a $\beta$-galactoside-binding lectin, exhibits pleiotropic biological functions and has been implicated in cell growth, differentiation, apoptosis, adhesion, malignant transformation and RNA processing (1-4). Galectin-3 is expressed intracellularly and extracellularly by numerous cell types.

Cytoplasmic galectin-3 acts as an apoptosis inhibitor in the cytoplasm and, in certain conditions, regulates trafficking between the cytoplasm and the nucleus (3). Nuclear galectin-3 has been reported to function as an mRNA splicing promoter (5). When expressed on the surface of tumor cells, galectin-3 has a role as an adhesion molecule in cell-to-cell or cell-to-matrix interactions (6). Circulating galectin-3 has been reported to be produced by activated macrophages, mast cells, eosinophils and tumor cells (7).

Galectin-3 also has a role as an immunological modulator by regulating cytokine production, phagocytosis, chemotaxis and apoptosis induction (8-12). As for cytokine production, galectin-3 has been reported to have inhibitory effects on interleukin-12 (IL-12) production by dendritic cells (9). Macrophages from galectin-3 deficient mice produce higher amounts of IL-10 compared with those from wild-type mice (11). The production of IL-6 has been reported to be influenced by galectin-3 through the tumor-producing galectin-3 binding protein (13). As for cellular immunity, galectin-3 has been shown to reduce the affinity of T-cell receptors (14), influence the strength of antigen activation 
in dendritic cells $(15,16)$, internalize T-cell receptors (17) and induce apoptosis of T cells (12). Galectin-3 also inhibits natural killer $(\mathrm{NK})$ cell-mediated tumor immunity by binding the natural cytotoxicity receptor, NKp30 or NKG2D $(18,19)$.

Previous studies have revealed an elevated concentration of serum galectin-3 in various cancers, including breast (20), colorectal (21,22), stomach (23), lung (20), bladder (24), head and neck (25), liver (26), thyroid (27), pancreatic (28) and melanoma (29). These studies demonstrated higher amounts of galectin-3 in the sera of patients and its association with poorer prognosis. However, the associations between galectin-3 and immunological and nutritional parameters remain to be elucidated.

The aim of the present study was to clarify the associations between circulating galectin-3 and host immunity and nutritional status. IL-10, IL-12 and IL17 production were examined by peripheral blood mononuclear cells (PBMCs) and lymphocyte stimulation assay as immunological parameters, neutrophil/lymphocyte ratio (NLR), white blood cell count (WBC) and C-reactive protein (CRP) as markers of inflammation, and rapid turnover proteins (RTP), such as retinol-binding protein (RBP), prealbumin (PA) and transferrin (TF) as parameters for nutritional condition.

\section{Materials and methods}

Patients. Blood samples were collected from 50 patients with colorectal cancer before starting treatment between April 2011 and August 2013. The patients included 8 with stage I disease, 12 with stage II disease, 18 with stage III disease, and 12 with stage IV disease. The enrolled patients underwent surgery or chemotherapy for the treatment of histologically confirmed cancer at the Department of Organ Regulatory Surgery, Fukushima Medical University (Fukushima, Japan). In addition, samples from 20 healthy volunteers of similar age and gender distributions were used as controls. The study protocol was approved by the ethics committee of Fukushima Medical University and written informed consent was obtained from the enrolled patients and healthy volunteers.

Blood samples. PBMCs were separated on Ficoll-Hypaque (Pharmacia-Biotech, Uppsala, Sweden) columns. The isolated PBMCs were washed twice with RPMI-1640 (Wako Pure Chemical Industries Ltd., Osaka, Japan). Sera from patients were stored at $-80^{\circ} \mathrm{C}$ until use.

Galectin-3 measurement. Serum concentrations of galectin-3 were measured using an enzyme-linked immunosorbent assay (ELISA; R\&D Systems, Minneapolis, MN, USA) according to the manufacturer's protocol.

Cytokine production by PBMCs. PBMCs, prepared using the aforementioned method, were incubated in $1 \mathrm{ml}$ of RPMI-1640 at a concentration of $10^{6}$ cells $/ \mathrm{ml}$ with $10 \%$ heat-inactivated fetal calf serum (Gibco; Thermo Fisher Scientific, Inc., Waltham, MA, USA) in $5 \% \mathrm{CO}_{2}$ at $37^{\circ} \mathrm{C}$ for $24 \mathrm{~h}$ with appropriate stimulations: With $20 \mu \mathrm{g} / \mathrm{ml}$ phytohemagglutinin (PHA) for IL-10 and IL-17 production assays, and with $0.01 \%$ of Staphylococcus aureus Cowan-1 for the IL-12 production assays. Aliquots of these supernatants were frozen and stored
A

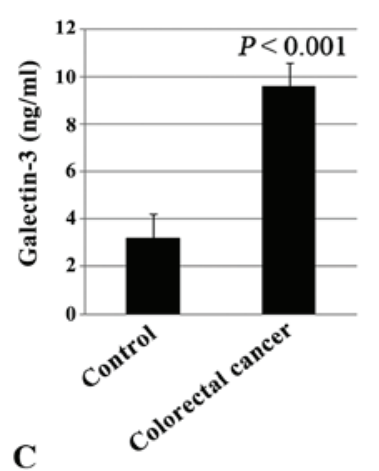

B

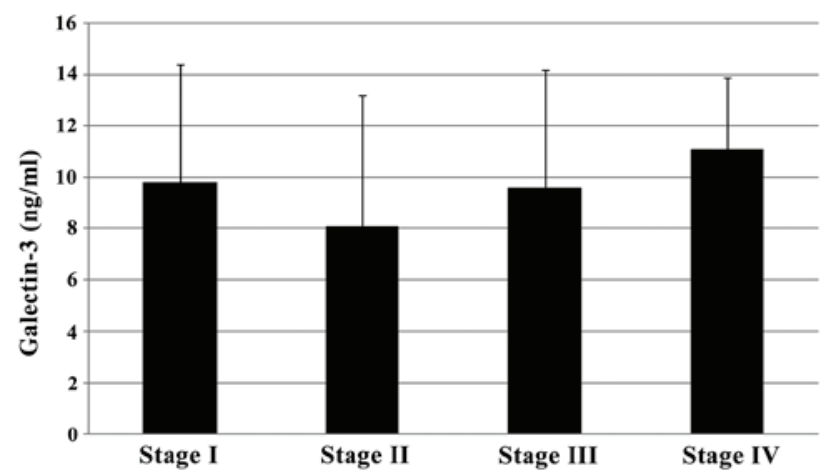

Figure 1. Concentration of serum galectin-3 in patients with colorectal cancer. (A) Significant increases $(\mathrm{P}<0.05)$ were observed in serum galectin-3 levels in patients with untreated colorectal cancer compared with normal controls. (B) When serum galectin-3 concentrations were compared between patients with colon cancer $(n=23)$ and patients with rectal cancer $(n=27)$, the levels of serum galectin-3 in patients with colon cancer were significantly higher than those in patients with rectal cancer $(\mathrm{P}=0.005)$. (C) No statistically significant differences were observed in the levels of serum galectin-3 between the different stages.

at $-80^{\circ} \mathrm{C}$ until use. Supernatant samples were subsequently thawed and used for measurements of IL-10, IL-12 and IL-17 concentrations using ELISA (R\&D Systems). Each sample was used only once subsequent to thawing.

Lymphocyte stimulation assay. A lymphocyte proliferation assay was performed using prepared PBMCs suspended in RPMI-1640 containing 10\% fetal calf serum. After the addition of $10 \mu \mathrm{g} / \mathrm{ml} \mathrm{PHA}$ into PBMC culture wells stored at $37^{\circ} \mathrm{C}$ in a $5 \% \mathrm{CO}_{2}$ atmosphere, mitogenesis was observed for $80 \mathrm{~h}$. ${ }^{3} \mathrm{H}$-thymidine (Japan Radioisotope Association, Tokyo, Japan) was added to wells for the last $8 \mathrm{~h}$ of incubation. Cells were harvested and $3 \mathrm{H}$-thymidine incorporation was determined using a liquid scintillation counter (Perkin-Elmer, Waltham, MA, USA) and expressed as counts per minute (cpm). The stimulation index (SI) was obtained by calculating total $\mathrm{cpm} /$ control $\mathrm{cpm}$. The controls were PBMCs without PHA addition.

Parameters for nutritional status and inflammation. The patient nutritional statuses were determined by measuring serum concentrations of RBP (latex agglutination immunoassay), PA (turbidimetric immunoassay) (30) and TF (turbidimetric immunoassay) (31). Neutrophil and lymphocyte counts, as well as NLR, were used as indicators of inflammation. 
Statistical analysis. Differences between the groups were analyzed using the Student's t-test. Associations between two variables were quantified using the Spearman's rank correlation coefficient. $\mathrm{P}<0.05$ was considered to indicate a statistically significant difference. All the statistical calculations were performed using SPSS ${ }^{\circledR}$ version 22 (IBM Corp. Japan, Tokyo, Japan). Not all blood samples were of sufficient volume for all measurements.

\section{Results}

Serum galectin-3 levels in patients with untreated colorectal cancer. As shown in Fig. 1A, significant increases $(\mathrm{P}<0.05)$ were observed in serum galectin-3 levels in patients with untreated colorectal cancer $(9.6 \pm 4.5 \mathrm{ng} / \mathrm{ml})$ compared with normal controls $(3.2 \pm 1.6 \mathrm{ng} / \mathrm{ml})$. When serum galectin-3 concentrations were compared between patients with colon cancer $(n=23)$ and patients with rectal cancer $(n=27)$, the levels of serum galectin-3 in patients with colon cancer $(11.5 \pm 4.4 \mathrm{ng} / \mathrm{ml})$ were significantly higher than those in patients with rectal cancer $(8.0 \pm 4.0 \mathrm{ng} / \mathrm{ml}$ ) (Fig. $1 \mathrm{~B}, \mathrm{P}=0.005)$. However, no statistically significant differences were observed in the levels of serum galectin-3 between the different stages $(9.8 \pm 4.6,8.1 \pm 5.1,9.6 \pm 4.6$ and $11.1 \pm 2.8 \mathrm{ng} / \mathrm{ml}$ for stages $1-4$, respectively; Fig. 1C).

Correlation between the galectin-3 serum concentrations and the immunological parameters. Fig. 2 shows the results of the correlation analysis between the galectin-3 serum concentrations and the immunological parameters. The amount of circulating galectin-3 inversely correlated with the production of IL-10 ( $\mathrm{r}=-0.59, \mathrm{P}<0.001)$ and IL-12 ( $\mathrm{r}=-0.69, \mathrm{P}<0.001)$. The serum concentration of galectin-3 also inversely correlated with the SI $(\mathrm{r}=-0.42, \mathrm{P}=0.021)$. By contrast, the level of serum galectin-3 correlated with the production of IL-17 $(r=0.67$, $\mathrm{P}<0.001)$.

Correlation analysis between the galectin-3 serum concentrations and inflammation indicators. Fig. 3 shows the results of the correlation analysis between the galectin-3 serum concentrations and inflammation indicators. The levels of serum galectin-3 exhibited significant correlations with NLR ( $\mathrm{r}=0.41$, $\mathrm{P}=0.009)$, WBC $(\mathrm{r}=0.32, \mathrm{P}=0.035)$ and $\mathrm{CRP}(\mathrm{r}=0.63, \mathrm{P}<0.001)$.

Correlation analyses in association with the nutritional parameters. The results of the correlation analyses in association with the nutritional parameters are summarized in Fig. 4. The level of serum galectin-3 exhibited statistically significant inverse correlations with $\mathrm{RBP}(\mathrm{r}=-0.45, \mathrm{P}=0.002), \mathrm{PA}(\mathrm{r}=-0.46$, $\mathrm{P}=0.001)$ and $\mathrm{TF}(\mathrm{r}=-0.72, \mathrm{P}<0.001)$.

\section{Discussion}

In accordance with the previous studies, the serum concentration of galectin-3 in the cancer patients was significantly higher compared to the healthy volunteers. However, no statistically significant differences were observed when comparing disease stages. Immunohistochemicaly, strong expression of galectin-3 has been reported to be associated with disease progression and metastasis $(32,33)$. The sources of circulating galectin-3
A
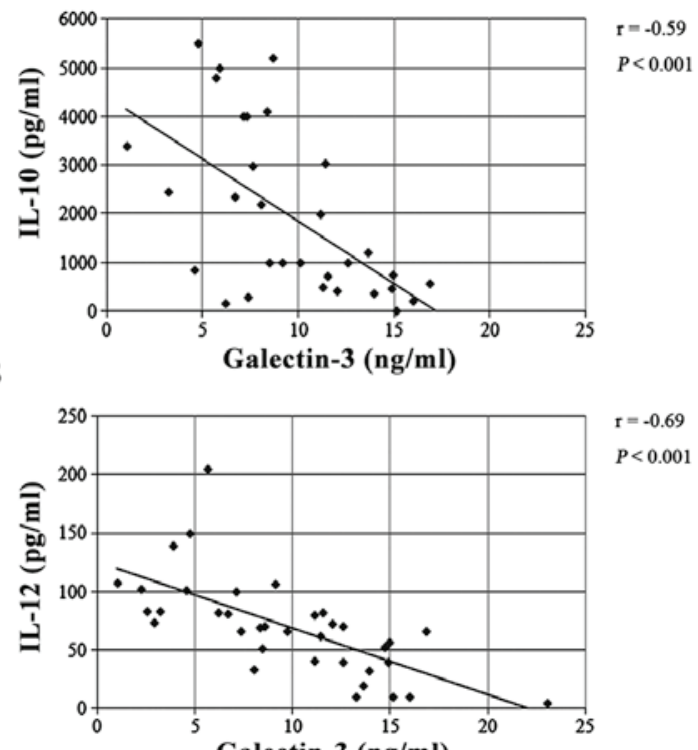

$r=-0.69$

$P<0.001$

C

Galectin-3 (ng/ml)
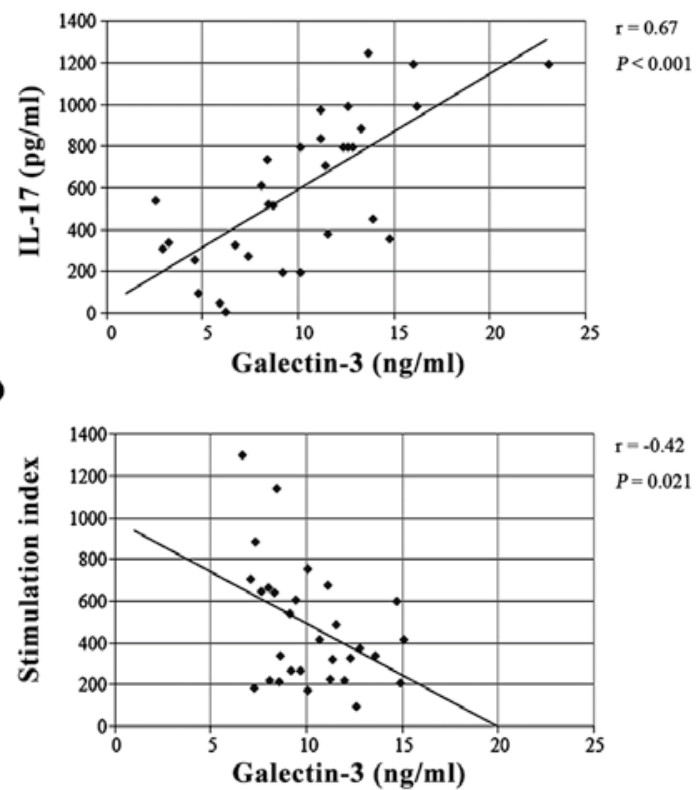

Figure 2. Correlations between the galectin-3 serum concentrations and immunological parameters. The amount of circulating galectin-3 inversely correlated with the production of (A) IL-10 ( $r=-0.59, \mathrm{P}<0.001)$ and (B) IL-12 $(\mathrm{r}=-0.69, \mathrm{P}<0.001)$. The serum concentration of galectin-3 also inversely correlated with the (D) stimulation index $(r=-0.42, P=0.021)$. By contrast, the level of serum galectin-3 correlated with the production of (C) IL-17 ( $r=0.67$, $\mathrm{P}<0.001)$. IL, interleukin.

are not only tumor cells, but also macrophages, mast cells and eosinophils $(7,20)$. Thus, the circulating level of galectin-3 is not always representative of the expression level of galectin- 3 in the tumor microenvironment. The reason for why the levels of serum galectin-3 in patients with colon cancer were significantly higher compared to those in patients with rectal cancer remains to be elucidated.

The amount of circulating galectin-3 showed a significant correlation with IL-17 production, whereas an inverse correlation was observed with IL-12 production. To the best of our knowledge, the present study reports for the first time the association between galectin-3 and IL-17 production, while 
A

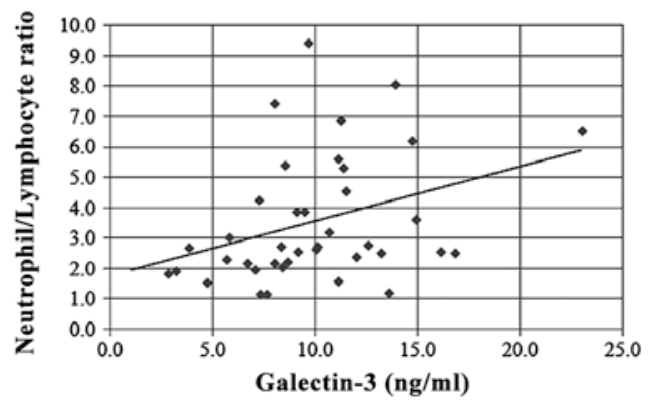

B

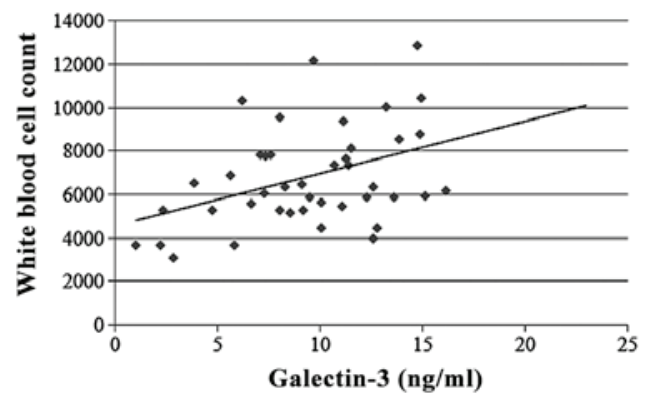

C

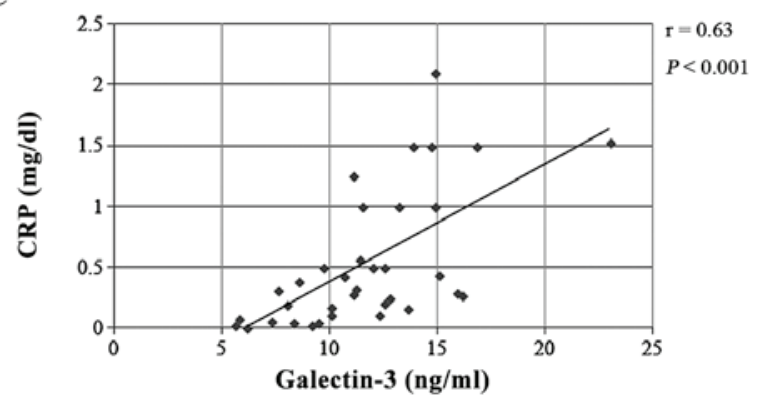

Figure 3. Correlations between the galectin-3 serum concentrations and inflammation indicators. The levels of serum galectin-3 exhibited significant correlations with (A) neutrophil/lymphocyte ratio $(\mathrm{r}=0.41, \mathrm{P}=0.009)$, (B) white blood cell count $(\mathrm{r}=0.32, \mathrm{P}=0.035)$ and $(\mathrm{C}) \mathrm{CRP}(\mathrm{r}=0.63, \mathrm{P}<0.001)$. CRP, C-reactive protein.

galectin-3 has been reported to have inhibitory effects on IL-12 production by dendritic cells (9). Our previous study reported that increased IL-17 production correlated with cellular immunosuppression (34). Thus, cell-mediated immunity may be depressed through Th2-dominant conditions driven by depressed IL-12 production. By contrast, the production of IL-10, which is a potent immunosuppressive cytokine produced primarily by Th 2 cells, macrophages and activated B cells, showed inverse correlation with the amount of circulating galectin-3. The direct effects of galectin-3 on IL-10, IL-12 and IL-17 production should be assessed in the future.

As for indicators of inflammation, NLR, WBC and CRP exhibited significant correlations with the level of serum galectin-3. The present study supports a previous study that galectin-3 is associated with systemic inflammation and fibrosis (7). Systemic chronic inflammation has been reported to have a role in tumor development and growth, and importantly in the suppression of tumor immunity $(35,36)$.

The assessment of nutritional status is essential for a diagnosis of nutritional compromise, and measurements of serum concentrations of RTPs such as RBP, PA and TF have been
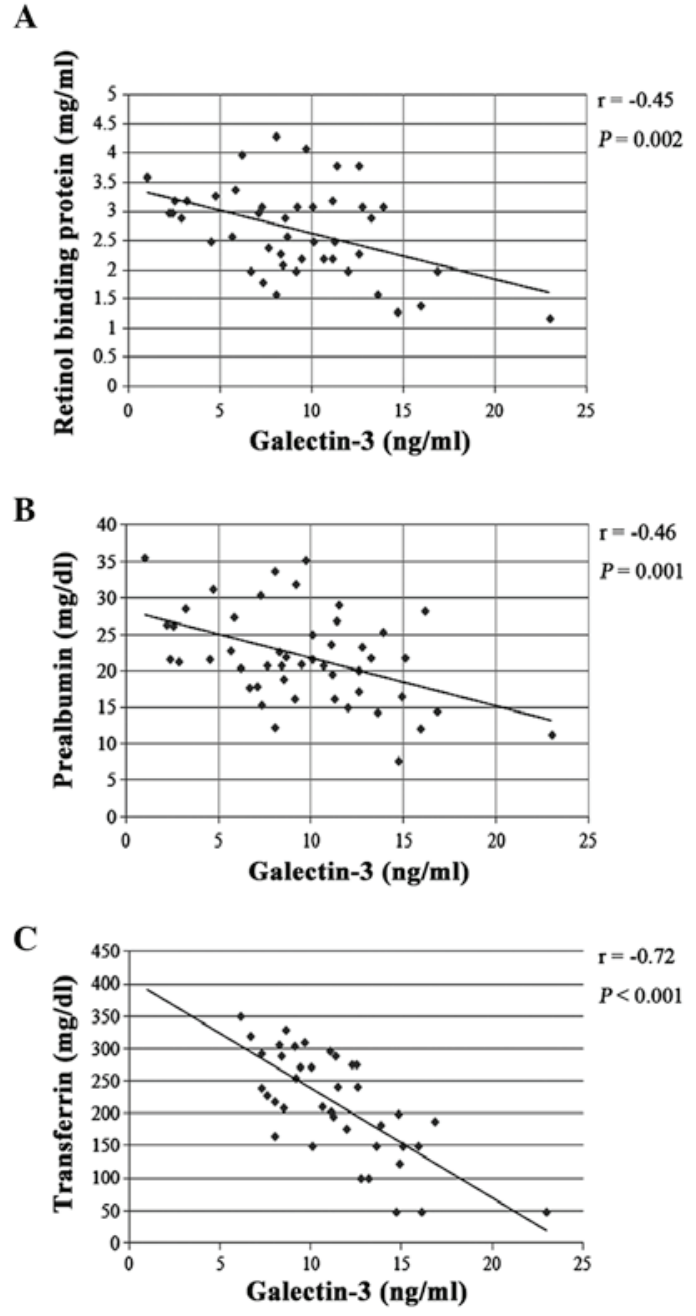

Figure 4. Correlations between serum galectin-3 concentration and nutritional parameters. The level of serum galectin- 3 exhibited statistically significant inverse correlations with (A) retinol-binding protein $(\mathrm{r}=-0.45$, $\mathrm{P}=0.002)$, $(\mathrm{B})$ prealbumin $(\mathrm{r}=-0.46, \mathrm{P}=0.001)$ and $(\mathrm{C})$ transferrin $(\mathrm{r}=-0.72$, $\mathrm{P}<0.001)$.

reported to be more accurate for this assessment in comparison to albumin (37-39). The serum concentration of galectin-3 showed a significant inverse correlation with assessed RTPs. The key mechanisms leading to cancer cachexia in which nutritional impairment is a major clinical issue, are mostly immune reactions caused by chronic inflammation. Galectin-3 may be one of the key factors in the regulation of immunological, inflammatory and nutritional conditions.

\section{References}

1. Akahani S, Nangia-Makker P, Inohara H, Kim HR and Raz A: Galectin-3: A novel antiapoptotic molecule with a functional BH1 (NWGR) domain of Bcl-2 family. Cancer Res 57: 5272-5276, 1997.

2. Danguy A, Camby I and Kiss R: Galectins and cancer. Biochim Biophys Acta 1572: 285-293, 2002.

3. Davidson PJ, Davis MJ, Patterson RJ, Ripoche MA, Poirier F and Wang JL: Shuttling of galectin-3 between the nucleus and cytoplasm. Glycobiology 12: 329-337, 2002.

4. Lin HM, Pestell RG, Raz A and Kim HR: Galectin-3 enhances cyclin $\mathrm{D}(1)$ promoter activity through $\mathrm{SP} 1$ and a cAMP-responsive element in human breast epithelial cells. Oncogene 21: 8001-8010, 2002. 
5. Dagher SF, Wang JL and Patterson RJ: Identification of galectin-3 as a factor in pre-mRNA splicing. Proc Natl Acad Sci USA 92: $1213-1217,1995$

6. Newlaczyl AU and Yu LG: Galectin-3 - a jack-of-all-trades in cancer. Cancer Lett 313: 123-128, 2011.

7. de Boer RA, van Veldhuisen DJ, Gansevoort RT, Muller Kobold AC, van Gilst WH, Hillege HL, Bakker SJL and van der Harst P: The fibrosis marker galectin-3 and outcome in the general population. J Intern Med 272: 55-64, 2012.

8. Acosta-Rodríguez EV, Montes CL, Motrán CC, Zuniga EI, Liu FT, Rabinovich GA and Gruppi A: Galectin-3 mediates IL-4-induced survival and differentiation of B cells: Functiona cross-talk and implications during Trypanosoma cruzi infection. J Immunol 172: 493-502, 2004.

9. Bernardes ES, Silva NM, Ruas LP, Mineo JR, Loyola AM, Hsu DK, Liu FT, Chammas R and Roque-Barreira MC: Toxoplasma gondii infection reveals a novel regulatory role for galectin-3 in the interface of innate and adaptive immunity. Am J Pathol 168: 1910-1920, 2006.

10. Ferraz LC, Bernardes ES, Oliveira AF, Ruas LP, Fermino ML, Soares SG, Loyola AM, Oliver C, Jamur MC, Hsu DK, et al: Lack of galectin-3 alters the balance of innate immune cytokines and confers resistance to Rhodococcus equi infection. Eur J Immunol 38: 2762-2775, 2008.

11. Ruas LP, Bernardes ES, Fermino ML, de Oliveira LL, Hsu DK, Liu FT, Chammas R and Roque-Barreira MC: Lack of galectin-3 drives response to Paracoccidioides brasiliensis toward a Th2-biased immunity. PLoS One 4: e4519, 2009.

12. Fukumori T, Takenaka Y, Yoshii T, Kim HR, Hogan V, Inohara H, Kagawa S and Raz A: CD29 and CD7 mediate galectin-3-induced type II T-cell apoptosis. Cancer Res 63: 8302-8311, 2003.

13. Silverman AM, Nakata R, Shimada H, Sposto $R$ and DeClerck YA: A galectin-3-dependent pathway upregulates interleukin-6 in the microenvironment of human neuroblastoma. Cancer Res 72: 2228-2238, 2012

14. Demotte N, Wieërs G, Van Der Smissen P, Moser M, Schmidt C, Thielemans K, Squifflet JL, Weynand B, Carrasco J, Lurquin C, et al: A galectin-3 ligand corrects the impaired function of human CD4 and CD8 tumor-infiltrating lymphocytes and favors tumor rejection in mice. Cancer Res 70: 7476-7488, 2010.

15. Breuilh L, Vanhoutte F, Fontaine J, van Stijn CM, Tillie-Leblond I, Capron M, Faveeuw C, Jouault T, van Die I, Gosset P, et al: Galectin-3 modulates immune and inflammatory responses during helminthic infection: Impact of galectin-3 deficiency on the functions of dendritic cells. Infect Immun 75: 5148-5157, 2007.

16. Wu SY, Yu JS, Liu FT, Miaw SC and Wu-Hsieh BA: Galectin-3 negatively regulates dendritic cell production of IL-23/IL-17-axis cytokines in infection by Histoplasma capsulatum. J Immunol 190: 3427-3437, 2013.

17. Chen HY, Fermin A, Vardhana S, Weng IC, Lo KF, Chang EY, Maverakis E, Yang RY, Hsu DK, Dustin ML and Liu FT: Galectin-3 negatively regulates TCR-mediated CD4+ T-cell activation at the immunological synapse. Proc Natl Acad Sci USA 106: 14496-14501, 2009.

18. Wang W, Guo H, Geng J, Zheng X, Wei H, Sun R and Tian Z: Tumor-released Galectin-3, a soluble inhibitory ligand of human NKp30, plays an important role in tumor escape from NK cell attack. J Biol Chem 289: 33311-33319, 2014.

19. Tsuboi S, Sutoh M, Hatakeyama S, Hiraoka N, Habuchi T, Horikawa Y, Hashimoto Y, Yoneyama T, Mori K, Koie T, et al: A novel strategy for evasion of NK cell immunity by tumours expressing core2 O-glycans. EMBO J 30: 3173-3185, 2011.

20. Iurisci I, Tinari N, Natoli C, Angelucci D, Cianchetti E and Iacobelli S: Concentrations of galectin-3 in the sera of normal controls and cancer patients. Clin Cancer Res 6: 1389-1393, 2000

21. Iacovazzi PA, Notarnicola M, Caruso MG, Guerra V, Frisullo S, Altomare DF and Correale M: Serum levels of galectin-3 and its ligand $90 \mathrm{k} / \mathrm{mac}-2 \mathrm{bp}$ in colorectal cancer patients Immunopharmacol Immunotoxicol 32: 160-164, 2010.
22. Chen C, Duckworth CA, Zhao Q, Pritchard DM, Rhodes JM and Yu LG: Increased circulation of galectin-3 in cancer induces secretion of metastasis-promoting cytokines from blood vascular endothelium. Clin Cancer Res 19: 1693-1704, 2013.

23. Cheng D, Liang B and Li Y: Serum galectin-3 as a potential marker for gastric cancer. Med Sci Monit 21: 755-760, 2015

24. Sakaki M, Oka N, Nakanishi R, Yamaguchi K, Fukumori T and Kanayama HO: Serum level of galectin-3 in human bladder cancer. J Med Invest 55: 127-132, 2008.

25. Saussez S, Lorfevre F, Lequeux T, Laurent G, Chantrain G, Vertongen F, Toubeau G, Decaestecker C and Kiss R: The determination of the levels of circulating galectin-1 and -3 in HNSCC patients could be used to monitor tumor progression and/or responses to therapy. Oral Oncol 44: 86-93, 2008.

26. Ulu M, Alacacioglu A, Yuksel E, Pamukk BO, Bozkaya G, Ari A, Yuksel A, Sop G and Alacacioglu I: Prognostic significance of serum galectin-3 levels in patients with hepatocellular cancer and chronic viral hepatitis. Saudi J Gastroenterol 21: 47-50, 2015.

27. Išić T, Savin S, Cvejić D, Marečko I, Tatić S, Havelka M and Paunović I: Serum Cyfra 21.1 and galectin-3 protein levels in relation to immunohistochemical cytokeratin 19 and galectin-3 expression in patients with thyroid tumors. J Cancer Res Clin Oncol 136: 1805-1812, 2010.

28. Xie L, Ni WK, Chen XD, Xiao MB, Chen BY, He S, Lu CH, $\mathrm{Li}$ XY, Jiang F and Ni RZ: The expressions and clinical significances of tissue and serum galectin-3 in pancreatic carcinoma. J Cancer Res Clin Oncol 138: 1035-1043, 2012.

29. Vereecken P, Zouaoui Boudjeltia K, Debray C, Awada A, Legssyer I, Sales F, Petein M, Vanhaeverbeek M, Ghanem G and Heenen M: High serum galectin-3 in advanced melanoma: Preliminary results. Clin Exp Dermatol 31: 105-109, 2006.

30. Bergström K and Lefvert AK: An automated turbidimetric immunoassay for plasma proteins. Scand J Clin Lab Invest 40: 637-640, 1980.

31. Kleine TO and Merten B: Rapid manual immunoturbidimetric and immunonephelometric assays of prealbumin, albumin, IgG, IgA and IgM in cerebrospinal fluid. J Clin Chem Clin Biochem 18: 245-254, 1980.

32. Hittelet A, Legendre H, Nagy N, Bronckart Y, Pector JC, Salmon I, Yeaton P, Gabius HJ, Kiss R and Camby I: Upregulation of galectins-1 and -3 in human colon cancer and their role in regulating cell migration. Int J Cancer 103: 370-379, 2003.

33. Nakamura $M$, Inufusa $H$, Adachi $T$, Aga $M$, Kurimoto $M$, Nakatani Y, Wakano T, Nakajima A, Hida JI, Miyake M, et al: Involvement of galectin-3 expression in colorectal cancer progression and metastasis. Int J Oncol 15: 143-148, 1999.

34. Yazawa T, Shibata M, Gonda K, Machida T, Suzuki S, Kenjo A, Nakamura I, Tsuchiya T, Koyama Y, Sakurai K, et al: Increased IL-17 production correlates with immunosuppression involving myeloid-derived suppressor cells and nutritional impairment in patients with various gastrointestinal cancers. Mol Clin Oncol 1: 675-679, 2013.

35. Balkwill $\mathrm{F}$ and Mantovani A: Cancer and inflammation: Implications for pharmacology and therapeutics. Clin Pharmacol Ther 87: 401-406, 2010.

36. Coussens LM and Werb Z: Inflammation and cancer. Nature 420: 860-867, 2002.

37. Inoue Y, Nezu R, Matsuda H, Takagi Y and Okada A: Rapid turnover proteins as a prognostic indicator in cancer patients. Surg Today 25: 498-506, 1995.

38. Vanlandingham S, Spiekerman AM and Newmark SR: Prealbumin: A parameter of visceral protein levels during albumin infusion. JPEN J Parenter Enteral Nutr 6: 230-231, 1982.

39. Delpeuch F, Cornu A and Chevalier P: The effect of iron-deficiency anaemia on two indices of nutritional status, prealbumin and transferrin. Br J Nutr 43: 375-379, 1980. 